\title{
Response of Irrigation and Fertigation Management on Growth and Yield of Maize
}

\author{
S.M. Bibe*, K.T. Jadhav and A.S. Chavan \\ Department of Agronomy, VNMKV, Parbhani- 431402 (MS), India \\ *Corresponding author
}

\section{Keywords \\ Irrigation levels, Fertigation levels, Maize.}

\section{Article Info}

Accepted:

28 September 2017

Available Online:

10 November 2017

\section{A B S T R A C T}

A field experiment was carried out at AICRP on Irrigation Water Management, V.N.M.K.V., Parbhani during kharif season of 2015-16 on clayey soil. The experiment was laid in split plot design with twelve treatments consisting of three combinations of irrigation as main plot and four combinations of fertigation as sub plot treatments replicated thrice. Treatments consist of Main plot treatments - Irrigation Levels viz., $0.6 \mathrm{x}$ P.E through drip, $0.8 \times$ P.E through drip, $1.0 \times$ P.E through drip and Subplot treatments: Fertigation Levels Viz., $100 \%$ RDF through Fertigation, $75 \%$ RDF through Fertigation, $50 \%$ RDF through Fertigation, 100\%RDF as soil application. Growth parameters like plant height $(\mathrm{cm})$, dry matter production $(\mathrm{g})$, number of grains per cob, cob weight per plant, grain weight per plant, and number of grain row per cob were significantly higher with irrigation at 1.0 PE $\left(\mathrm{I}_{1}\right)$ over the $0.6 \mathrm{PE}\left(\mathrm{I}_{3}\right)$ and comparable with $0.8 \mathrm{PE}\left(\mathrm{I}_{2}\right)$ at all observations. Application of fertilizer @ 100\% RDF through drip $\left(\mathrm{F}_{1}\right)$ recorded significantly highest growth parameters like plant height $(\mathrm{cm})$, and dry matter production (g), number of grains per cob, cob weight per plant, grain weight per plant, number of grain row per cob over the application of fertilizer with $100 \%$ RDF through soil $\left(\mathrm{F}_{4}\right)$ and $50 \%$ RDF through drip $\left(\mathrm{F}_{3}\right)$, respectively but it was on par with $75 \%$ RDF through drip $\left(\mathrm{F}_{2}\right)$. Significantly lowest growth parameters were recorded at 50\% RDF through drip $\left(\mathrm{F}_{3}\right)$ and were at par with $100 \%$ RDF through drip $\left(\mathrm{F}_{4}\right)$.

\section{Introduction}

Maize (Zea mays L.) also called corn, is one of the most crucial and strategic crop in the world. Its origin is in Mexico (Central America) and it is also called as queen of cereals due to its great importance in human, animal diet and high yielding ability. It efficiently utilizes solar energy and has immense potential for higher yield, and called as "Miracle Crop". It is the crop of the future as mentioned by the Father of Green Revolution, Renounced Nobel Laureate Dr. Norman E. Borlaug. Maize plays a vital role in ensuring food security as well as nutritional security through quality protein (Rawool, 2004). It is ranked third after wheat and rice in area and production but in productivity, it surpasses all cereals. Among the maize producing countries in 2014, USA has the largest area and production (314 million tonnes) followed by China, Brazil, Ukraine, India, Argentina, Mexico etc. Worldwide production of maize is 785 million tonnes, of which USA produces $42 \%$ Asia produces $28.5 \%$ and Africa contributing 6.4\%. Maize 
accounts 22 and $25 \%$ of world cereal area and production, respectively (Anonymous, 2015). In India, area and production of maize is about 9.43 million hectares, 24.35 million tones, respectively, having average productivity of about $2337 \mathrm{~kg} / \mathrm{ha}$ (www.indiastat.com/maize). It ranked next to rice, wheat and sorghum in respect of area and production. Though it is consumed all over the country but it is a staple food of people in hilly and sub mountain area of North India. It is extensively grown in Uttar Pradesh, Bihar, Rajasthan, Madhya Pradesh etc. (Dayannad and Jain, 1994). In Maharashtra, the area and production of maize is about 0.58 million hectares and 1.15 million tonnes production with the productivity of $2066 \mathrm{~kg} / \mathrm{ha}$ (Anonymous, 2014). It is well known that maize is a heavy feeder crop and it gives response to fertilization, especially where soils are generally low in native fertility. It is generally observed that maize fails to produce worthwhile grain yield in plots without fertilizer application (Kumar, 1993). Soil fertility is a major constraint for its productivity, low organic matter content coupled with low and imbalance application of nutrients limits its full potential yield and is the main yield barrier (Bellakki et al., 1999, Kalane 1998). Considering the commercial demand of maize its productivity needs to be increased. This can be easily possible through manipulation of major input factor like irrigation and fertigation. However, the work on these aspects in maize is very meager, particularly in post rainy season. Therefore, the importance of these aspects in maize production, an experiment was planned on Studies on irrigation and fertigation management in post Kharif maize.

\section{Materials and Methods}

A field experiment was conducted during kharif season of 2015-16 at AICRP on
Irrigation Water Management, V.N.M.K.V., Parbhani with objectives to study the performance of maize under irrigation levels in post kharif season, to determine optimum fertigation levels for maize in post kharif season and to study the interaction effect of irrigation and fertigation levels on maize in post kharif season. The topography of field was fairly uniform and leveled.

The soil was clayey in texture, medium in total nitrogen and available phosphorus, high in potassium and slightly alkaline in reaction Sowing was done by dibbling method on September 9, 2015. The experiment was laid out in split plot design with twelve treatments consisting of three combinations of irrigation as main plot and four combinations of fertigation as sub plot treatments replicated thrice. The layout consisted of thirty three plots with gross plot size of $6.0 \mathrm{~m} \times 5.0 \mathrm{~m}$ and net plot size of $3.6 \mathrm{~m} \mathrm{x} 4.4 \mathrm{~m}$.

\section{Results and Discussion}

\section{Effect of irrigation levels}

\section{Growth attributes}

Data on growth attributes during present investigation (Table 1) revealed that irrigation scheduled at $1.0 \mathrm{PE}\left(\mathrm{I}_{1}\right)$ recorded maximum plant height, and dry matter per plant at all observation dates. This was followed by irrigation at $0.8\left(\mathrm{I}_{2}\right)$ and irrigation at $0.6\left(\mathrm{I}_{3}\right)$, respectively for all growth attributes at all crop growth stages this trend in growth attributes showed that maize responded linearly with increasing irrigation levels from 0.6 PE to 1.0 PE this also indicated that there is higher water requirement for maize to obtain better growth of the crop. Better growth attributes with increased irrigation level also reported by Bharti et al., (1997), Abdullah et al., (2001), Bharti et al., (2007), Patil et al., (2008) and Basva et al., (2012). 
Better growth of maize under drip might be attributed to better moisture availability, soil aeration and also crop did not experience stress during the crop growth period at $1.0 \mathrm{PE}$ irrigation schedule this ultimately reflected better physiological activity in plant and there by increased plant height, and dry matter production per plant. Similarly findings were reported by Thorat and Ramteke (1991) and Leta Tulu (1998).

\section{Yield attributes}

Data pertaining to yield attributes indicated that yield attributing characters viz., number of cobs per plant, average weight of cob, number of grain per cob and number of grain per row per cob, weight of grain per plant were significantly influenced by different treatments of irrigation (Table 1 and 2).

Amongst irrigation levels, 1.0 PE $\quad\left(\mathrm{I}_{1}\right)$ recorded significantly higher values of above referred yield attributing characters over 0.6 $\mathrm{PE}\left(\mathrm{I}_{3}\right)$ and was comparable with $0.8 \mathrm{PE}\left(\mathrm{I}_{2}\right)$. This might be due to the water stress under low PE which resulted in poor plant growth due to restriction imposed on nutrient translocation, photosynthesis and metabolic activities of plant system.

All these above referred yield attributes were decreased with subsequent decrease in the level of irrigation. These findings are in close conformity with those of Khan et al., (1996), Tyagi et al., (1998) and Bharti et al., (2007).

\section{Grain yield and fodder yield}

Irrigation levels significantly influenced the grain yield of maize. Drip irrigation at 1.0 PE. $\left(\mathrm{I}_{1}\right)$ registered significantly higher grain yield of maize than 0.6 PE $\left(\mathrm{I}_{3}\right)$ and was at par with $0.8 \mathrm{PE}\left(\mathrm{I}_{2}\right)$ (Table 3). This might be attributed to better growth and yield attributes under 1.0 $\mathrm{PE}\left(\mathrm{I}_{1}\right)$ compared to irrigation at lower $\mathrm{PE}$ values. Significantly higher grain yield, fodder yield and biological yield was observed with irrigation at $1.0 \mathrm{PE}\left(\mathrm{I}_{1}\right)$ than irrigation at $0.6 \mathrm{PE}\left(\mathrm{I}_{3}\right)$, however, it was found comparable with $0.8 \mathrm{PE}\left(\mathrm{I}_{2}\right)$.

Harvesting index showed little variation among irrigation levels, 1.0 PE $\left(\mathrm{I}_{1}\right)$ was numerically higher than rest of treatments followed by $0.8 \mathrm{PE}\left(\mathrm{I}_{2}\right)$ and $0.6 \mathrm{PE}\left(\mathrm{I}_{3}\right)$, respectively. This indicated little effect on sink-source relation due to fertigation levels.

\section{Effect of fertigation levels}

\section{Growth attributes}

Data on growth attributes at all observations indicated that $100 \%$ RDF through drip showed maximum plant height, and dry matter per plant than rest of the fertigation levels viz., $75 \%$ RDF through drip $\left(\mathrm{F}_{2}\right), 100 \%$ RDF through soil $\left(\mathrm{F}_{4}\right)$ and $50 \%$ RDF through drip $\left(\mathrm{F}_{3}\right)$, respectively. This might be attributed to better availability of nutrient under application of water soluble fertilizer which resulted in better or on par growth attributes with low fertigation levels i.e. $50 \%$ RDF and $75 \%$ RDF through drip over $100 \%$ RDF through soil. Similar results were found by Sampatkumar and Pandian (2010) and Muthukrishnan et al., (2011)

\section{Yield attributes}

Yield attributing characters of maize viz., number of cobs per plant, average weight of cob, number of grain per cob and number of grain row per cob, weight of grain per plant were differed statistically due to various fertigation levels (Table 3). 100\% RDF through drip $\left(\mathrm{F}_{1}\right)$ recorded significantly higher values of all above referred yield attributes over $100 \%$ RDF through soil application $\left(\mathrm{F}_{4}\right)$ and $50 \%$ RDF through fertigation $\left(\mathrm{F}_{3}\right)$, respectively. 
Table.1 Growth and yield attributes as influenced by different treatments

\begin{tabular}{|c|c|c|c|c|c|c|}
\hline Treatment & $\begin{array}{l}\text { plant height }(\mathrm{cm}), \\
\text { At harvest }\end{array}$ & $\begin{array}{l}\text { dry matter production } \\
\text { (g/plant) At harvest }\end{array}$ & No of cob/plant & $\begin{array}{c}\text { Cob weight/plant } \\
\text { (gm) }\end{array}$ & $\begin{array}{c}\text { Husk Weight/plant } \\
\text { (gm) }\end{array}$ & $\begin{array}{c}\text { Spindle weight/plant } \\
(\mathrm{gm})^{1}\end{array}$ \\
\hline \multicolumn{7}{|l|}{ IRRIGATION LEVELS } \\
\hline $\mathrm{I}_{1}$ at $1.0 \mathrm{PE}$ & 205.24 & 259.79 & 1.30 & 233.58 & 14.82 & 21.06 \\
\hline $\mathrm{I}_{2}$ at $0.8 \mathrm{PE}$ & 191.02 & 242.23 & 1.22 & 218.10 & 13.84 & 19.67 \\
\hline $\mathrm{I}_{3}$ at $0.6 \mathrm{PE}$ & 178.83 & 227.02 & 1.15 & 205.34 & 13.03 & 18.52 \\
\hline S.E \pm & 4.18 & 5.14 & 0.03 & 4.49 & 0.29 & 0.41 \\
\hline C.D at $5 \%$ & 16.40 & 20.19 & 0.10 & 17.64 & 1.12 & 1.59 \\
\hline \multicolumn{7}{|l|}{ FERTIGATION LEVELS } \\
\hline $\mathrm{F}_{1}$ at $100 \%$ RDF Through drip & 207.51 & 262.73 & 1.32 & 235.71 & 14.96 & 21.26 \\
\hline $\mathrm{F}_{2}$ at $75 \%$ RDF Through drip & 199.63 & 252.82 & 1.27 & 227.61 & 14.44 & 20.53 \\
\hline $\mathrm{F}_{3}$ at $50 \%$ RDF Through drip & 174.31 & 221.39 & 1.12 & 200.45 & 12.72 & 18.08 \\
\hline $\mathrm{F}_{4}$ at $100 \%$ RDF Through soil & 185.34 & 235.12 & 1.18 & 212.26 & 13.47 & 19.14 \\
\hline S.E \pm & 5.95 & 7.40 & 0.04 & 6.32 & 0.40 & 0.57 \\
\hline C.D at $5 \%$ & 17.68 & 21.99 & 0.11 & 18.78 & 1.19 & 1.69 \\
\hline \multicolumn{7}{|l|}{ Interaction (I x F) } \\
\hline S.E \pm & 10.30 & 12.82 & 0.06 & 10.95 & 0.70 & 0.99 \\
\hline C.D at $5 \%$ & NS & NS & NS & NS & $\mathrm{NS}$ & NS \\
\hline GM & 191.70 & 243.02 & 1.22 & 219.01 & 13.90 & 19.75 \\
\hline
\end{tabular}

Table.2 Growth and yield attributes as influenced by different treatments

\begin{tabular}{|c|c|c|c|c|}
\hline Treatment & No of grain/cob & No of grain row/cob & Grain weight/plant (gm) & 1000 grain weight $(\mathrm{gm})$ \\
\hline \multicolumn{5}{|l|}{ IRRIGATION LEVELS } \\
\hline $\mathrm{I}_{1}$ at $1.0 \mathrm{PE}$ & 483.70 & 14.06 & 186.77 & 322.58 \\
\hline $\mathrm{I}_{2}$ at $0.8 \mathrm{PE}$ & 451.64 & 13.13 & 174.39 & 306.49 \\
\hline $\mathrm{I}_{3}$ at $0.6 \mathrm{PE}$ & 425.22 & 12.36 & 164.19 & 302.26 \\
\hline S.E \pm & 9.31 & 0.27 & 3.59 & 9.70 \\
\hline C.D at $5 \%$ & 36.54 & 1.06 & 14.11 & NS \\
\hline \multicolumn{5}{|l|}{ FERTIGATION LEVELS } \\
\hline $\mathrm{F}_{1}$ at $100 \%$ RDF Through drip & 488.11 & 14.19 & 188.47 & 319.48 \\
\hline $\mathrm{F}_{2}$ at $75 \%$ RDF Through drip & 471.34 & 13.70 & 182.00 & 309.32 \\
\hline $\mathrm{F}_{3}$ at $50 \%$ RDF Through drip & 415.09 & 12.06 & 160.28 & 301.41 \\
\hline $\mathrm{F}_{4}$ at $100 \%$ RDF Through soil & 439.55 & 12.77 & 169.72 & 311.57 \\
\hline S.E \pm & 13.09 & 0.38 & 5.05 & 11.18 \\
\hline C.D at $5 \%$ & 38.89 & 1.13 & 15.02 & NS \\
\hline \multicolumn{5}{|l|}{ Interaction (I x F) } \\
\hline S.E \pm & 22.67 & 0.66 & 8.75 & 19.36 \\
\hline C.D at $5 \%$ & NS & $\mathrm{NS}$ & NS & $\mathrm{NS}$ \\
\hline GM & 453.52 & 13.18 & 175.12 & 310.44 \\
\hline
\end{tabular}


Table.3 Mean grain, spindle, husk, fodder, biological yield $(\mathrm{kg} / \mathrm{ha})$ and harvest index of maize as influenced by various levels of irrigation and fertigation

\begin{tabular}{|c|c|c|c|c|c|c|}
\hline Treatment & $\begin{array}{l}\text { Grain yield } \\
\text { (kg/ha) }\end{array}$ & $\begin{array}{l}\text { Husk weight } \\
\text { (kg/ha) }\end{array}$ & $\begin{array}{l}\text { Sp Spindle } \\
\text { weight } \\
\text { (kg/ha) }\end{array}$ & $\begin{array}{l}\text { Fodder yield } \\
\text { (kg/ha) }\end{array}$ & $\begin{array}{l}\text { Biological } \\
\text { yield (kg/ha) }\end{array}$ & $\begin{array}{l}\text { Harvest } \\
\text { index }\end{array}$ \\
\hline \multicolumn{7}{|l|}{ IRRIGATION LEVELS } \\
\hline $\mathrm{I}_{1}$ at $1.0 \mathrm{PE}$ & 8845.43 & 742.32 & 1100.62 & 12511.31 & 23199.69 & 38.12 \\
\hline $\mathrm{I}_{2}$ at $0.8 \mathrm{PE}$ & 8259.16 & 693.12 & 1027.67 & 11815.16 & 21795.13 & 37.89 \\
\hline $\mathrm{I}_{3}$ at $0.6 \mathrm{PE}$ & 7775.89 & 652.56 & 967.54 & 11213.07 & 20609.07 & 37.71 \\
\hline S.E \pm & 170.19 & 14.28 & 21.18 & 245.87 & 451.52 & - \\
\hline C.D at $5 \%$ & 668.15 & 56.07 & 83.14 & 965.25 & 1772.59 & - \\
\hline \multicolumn{7}{|l|}{ FERTIGATION LEVELS } \\
\hline $\mathrm{F}_{1}$ at $100 \%$ RDF Through drip & 8926.05 & 749.09 & 1110.66 & 12653.56 & 23436.50 & 38.08 \\
\hline $\mathrm{F}_{2}$ at $75 \% \mathrm{RDF}$ Through drip & 8619.30 & 723.34 & 1072.49 & 12251.64 & 22624.75 & 38.09 \\
\hline $\mathrm{F}_{3}$ at 50\% RDF Through drip & 7590.70 & 637.02 & 944.50 & 10928.25 & 20145.35 & 37.66 \\
\hline $\mathrm{F}_{4}$ at $100 \%$ RDF Through soil & 8037.92 & 674.55 & 1000.15 & 11552.61 & 21265.23 & 37.78 \\
\hline S.E \pm & 239.37 & 20.09 & 29.78 & 341.98 & 627.28 & - \\
\hline C.D at $5 \%$ & 711.22 & 59.69 & 88.50 & 1016.12 & 1863.81 & - \\
\hline \multicolumn{7}{|l|}{ Interaction (I x F) } \\
\hline S.E \pm & 414.60 & 34.79 & 51.59 & 592.33 & 1086.48 & - \\
\hline C.D at $5 \%$ & NS & NS & NS & NS & NS & - \\
\hline GM & 8293.49 & 696.00 & 1031.95 & 11846.52 & 21867.96 & 37.90 \\
\hline
\end{tabular}


However, the treatment $100 \%$ RDF through fertigation $\left(\mathrm{F}_{1}\right)$ was at par with $75 \% \mathrm{RDF}$ through fertigation $\left(\mathrm{F}_{2}\right)$ for all yield attributes. The lowest values of yield attributes were observed with 50\% RDF through drip $\left(\mathrm{F}_{3}\right)$ and were at par with $100 \%$ RDF through soil application $\left(\mathrm{F}_{4}\right)$. This effect was obviously due to high efficiency and easy availability of plant nutrients through the water soluble fertilizers. As availability of source in respect of maize increased with the increase in level of fertigation, the production in sink in the crop also followed same trend. These results are in conformity with those obtained by Hassanein et al., (2006)

Significantly higher grain yield, fodder yield and biological yield was observed with $100 \%$ RDF through drip $\left(\mathrm{F}_{1}\right)$ than $100 \%$ RDF through soil $\left(\mathrm{F}_{4}\right)$ and $50 \%$ RDF through drip $\left(\mathrm{F}_{3}\right)$, however, it was found comparable with $75 \%$ RDF through drip $\left(\mathrm{F}_{2}\right)$.

Harvest index showed little variation among fertigation levels, $75 \%$ RDF through drip $\left(\mathrm{F}_{2}\right)$ was numerically higher than rest of treatments followed by $100 \%$ RDF through drip $\left(F_{1}\right)$, $100 \%$ RDF through soil $\left(\mathrm{F}_{4}\right)$ and $50 \%$ RDF through drip $\left(\mathrm{F}_{3}\right)$, respectively. This indicated little effect on sink-source relation due to fertigation levels.

\section{Interaction effect}

Interaction effect due to different irrigation and fertigation levels were non-significant for all growth attributes, yield attributes, grain yield, fodder yield and biological yield.

\section{References}

Abdullah, K., Ismail, T.G., Yusuf, V. and Bdgin, C. (2001). Effect of mulch and irrigation water on Lettuce's yield, evapotranspiration and soil evaporation in Isparta location, Turkey. J. Biol. Sci,
4(6): 751-755.

Anonymous, (2014). The current status published on website - http: //www.indiastat.in.

Anonymous, (2015). The current status published on website - http: //www.fau.usda.gov/psdonline.

Basva Sharana, Sunita devi, Shivlakshmi, Y and P Surendrababu. (2012) Response of sweet corn hybrid to drip Fertigation J. of Res. ANGRAU 40(4):101-103.

Bellaki, M. A., Badanur, V. P., Faroda, A. S., Joshi, N. L., Kathju, S. and Kar, A. (1999). Integrated nutrient management for sustainable crop production (In) Proceeding of Symposium on Recent Advance in Management of Arid Ecosystem held in March 1997 at Jodhpor, pp 271-276.

Bharathi, A., Vadively, K.K. and R. Umarani (1997). Effect of irrigation management and nitrogen fertilization on shelf life of maize. Madras Agric. J., 84(7): 356360.

Bharti, V., Ravi Nandan, Vinod Kumar and I. B. Panday (2007). Effect of irrigation levels on yields, water use efficiency and economics of winter maize (Zea mays) - based intercropping systems. Indian J. Agron., 52(1): 27-30.

Hassanein, M.K.; Abdrabbo, M.A. and A.A. Farag (2006). Effect of different nitrogen levels on productivity of three maize hybrids through fertigation. Arab Universities, J. of Agril. Sciences.

Kalane R. L., Ghodpoge, R. M. and S. N. Ingale (1998). Moisture use pattern by hybrid sorghum under FYM and different levels of optimum NPK applied on vertisols. Ann. Plant Physiol., 12(1):23-28.

Khan (1996). Sweet corn response to surface and sub-surface trickle $\mathrm{P}$ fertigation. Agron. J., 81(3): 443-447.

Kumar, V., (1993). Crop production in the West Africa dry land. In: Dry land 
farming in Africa, J. R. J. Rowland (ed.) MacMillan Press Ltd., London, pp 109141.

Leta Tulu (1998). Response of maize (Zea mays L.) to moisture stress at different growth stages: A modeling approach. M.Sc. (Agri.) thesis, Univ. of Agril. Sciences, Bangalore.

Muthurakrishnan, $\mathrm{P}$ and S Anitta Fanish (2011). Influence of drip Fertigation on yield water saving and WUE in maize. Madras agric. J. 98(7-9): 243-247.

Rawool H. V. (2004). Effect of integrated nutrient management on yield and nutrient balance in maize (Zea mays $L$.). Indian J. Agril. Sci., 46(4) 698-701.

Sampatkumar T. and B. J. Pandian (2010) Effect Fertigation frequencies and levels on growth and yield of maize. Madras Agric.J. 97(7-9): 245-248.

Tyagi, R.C., Devender, Singh and I.S. Hooda (1998). Effect of plant population, irrigation and nitrogen on yield and its attributes of spring maize. Indian $J$. Agron., 43(4): 672.

\section{How to cite this article:}

Bibe, S.M., K.T. Jadhav and Chavan, A.S. 2017. Response of Irrigation and Fertigation Management on Growth and Yield of Maize. Int.J.Curr.Microbiol.App.Sci. 6(11): 4054-4060. doi: https://doi.org/10.20546/ijcmas.2017.611.474 